\title{
Detection of Rice Grassy Stunt Virus in Planthopper Vectors and Rice Plants by ELISA
}

\author{
Mabito IwaSaki*,**, Masaaki Nakano* and Akira ShinkaI*
}

\begin{abstract}
Filamentous particles associated with rice grassy stunt were purified from the infected rice plants. The filamentous particles were $6-12 \mathrm{~nm}$ in width. An antiserum to the filamentous particles specifically reacted to extracts of grassy stunt-infected leaves and-viruliferous planthoppers, Nilaparvata lugens by agar gel double diffusion test. The antibody neutralized the infectivity in extracts of grassy stunt-infected rice leaves. In enzyme-linked immunosorbent assay (ELISA), the filaments were detected in extracts of grassy stunt-exposed planthopper population up to a dilution of one planthopper $/ 8 \mathrm{ml}$ and also from extracts of the infected leaves at 1/100,000 dilution. Extracts of virus-free insects and healthy rice leaves did not give a positive reaction in ELISA. The purified filamentous nucleoprotein reacted positively even when diluted to $A_{260}=1.0 \times 10^{-5}$. The infective planthoppers stored at $25 \mathrm{C}$ for 1 month and the infected rice leaves stored at room temperature for 4 months gave positve reactions, but the intensity of the reactions was lower than that in fresh or frozen materials. In the exposed planthopper populations, $40 \%$ of the insects transmitted the causal agent and gave a positive reaction in ELISA, $41 \%$ failed to transmit the agent but gave a positive reaction, while both tests were negative in the remainder. The brown planthoppers that migrated across the South China Sea were collected and tested for the presence of the filaments in ELISA in 1982. About $0.1 \%$ of the total 1,126 individuals tested gave positive reaction.
\end{abstract}

(Received April 27, 1985)

Key Words : rice grassy stunt virus, Nilaparvata lugens, rice plant, ELISA.

\section{Introduction}

Rice grassy stunt (RGS) was reported for the first time in 1963 in the Philippines ${ }^{3)}$. The disease is distributed in South, Southeast and East Asia. In Japan, it was first detected in 1978 in Fukuoka and Kagoshima, Kyushur). The causal agent of RGS is transmitted by the brown planthopper, Nilaparvata lugens Stål, in a persistent manner ${ }^{13)}$. $N$. muiri and $N$. bakeri are the additional vector insects ${ }^{7}$, though they are not pests of rice plants and not important in the RGS epidemiology.

In Japan, no alternative hosts other than rice, Oryza sativa are known for $\mathrm{RGS}^{9,14)}$. It is impossible that RGS-infected rice stubbles serve as an infection source for the following year ${ }^{6)}$. Also, the brown planthopper is unable to overwinter. RGS agent is thus more likely to be brought into Japan through immigration of the planthoppers from the countries where the planthopper can overwinter ${ }^{4,6)}$. Effective RGS forecasting can

* Kyushu National Agricultural Experiment Station, Chikugo, Fukuoka 833, Japan 九州農業試験場 ** Present address : Shikoku National Agricultural Experiment Station, Zentsuji, Kagawa 765, Japan 四国農業試験場 
be achieved by monitoring immigrating planthoppers and percentage carriers of RGSagent.

The infectivity test of leaf extracts by microinjection into planthopper indicated that the causal agent of RGS showed characteristics of a virus ${ }^{3,5)}$. Association of isometric particles $20-25 \mathrm{~nm}$ in diameter with RGS was reported ${ }^{3,12,15)}$ and the particles were once suspected to be the pathogenic entities of $\mathrm{RGS}^{15)}$. Recently, however, circular filamentous nucleoprotein has been isolated from RGS-infected plants and the name "rice grassy stunt virus" was proposed for the filaments ${ }^{33}$.

In this report, we describe the association of the filamentous particles with rice grassy stunt disease, detection of the filaments in the brown planthoppers and rice plants by ELISA, and application of ELISA to monitoring planthopper immigrants carrying "rice grassy stunt virus".

\section{Materials and Methods}

Virus, insects and plants. RGS was collected at Takada-cho, Fukuoka in 1978 and maintained on rice seedlings by serial transmission using the brown planthoppers. Rice plants infected with rice dwarf, rice ragged stunt, rice stripe, rice yellow dwarf and rice waika were collected at Chikugo, Fukuoka in 1978, at Kagoshima in 1979, at Chikugo in 1982, at Togitsu-cho, Nagasaki in 1981 and at Chikugo in 1973, respectively. Virus-free planthoppers were originally collected at Kawanabe-cho, Kagoshima by T. Nagata, Kyushu National Agricultural Experiment Station. The viruliferous planthoppers were obtained by feeding virus-free nymphs in the second or third instar on a RGS-infected rice plant for 4-6 days. The planthoppers were fed on healthy rice seedlings for 6-10 days, and used for inoculation accesses. Rice seedlings (cultivar Taichung Native 1) were inoculated with RGS by using the viruliferous planthoppers and grown in a greenhouse. For the infectivity test, individual planthoppers were allowed a 2-day inoculation access period on rice seedlings (cultivar Reiho) in test tubes. Immigrant planthoppers were collected at three locations in June and July, 1982. Collections were made from rice hills in a paddy field using an aspirator at Chikugo, Fukuoka, by light trap at Isahaya, Nagasaki by Y. Ogawa, Nagasaki Agricultural and Forestry Experiment Station, and by airborne net trap at the weather station on the East China Sea $\left(\mathrm{N} 31^{\circ} 30^{\prime}\right.$, E $127^{\circ}$ ) by $\mathrm{T}$. Wada, Kyushu National Agricultural Experiment Station.

Purification. Purification of the RGS virus agent was attempted by following the modified method from that described by Shikata et al. ${ }^{15}$. RGS-infected rice leaves (200 g) stored at $-80 \mathrm{C}$ were homogenized with $600 \mathrm{ml}$ of $0.2 \mathrm{M}$ Tris buffer ( $\mathrm{pH} 6.5$ ) containing $0.01 \mathrm{M}$ thioglycolic acid. The homogenate was squeezed through a cheesecloth and centrifuged for $15 \mathrm{~min}$ at $17,000 \times \mathrm{g}$. The supernatant was filtered twice through a layer of celite in a Buchner's funnel, and stirred with $20 \%(\mathrm{v} / \mathrm{v})$ of $\mathrm{CCl}_{4}$ and $1 \%$ Triton X-100 for $15 \mathrm{~min}$ at $5 \mathrm{C}$. After centrifugation for $15 \mathrm{~min}$ at $17,000 \times \mathrm{g}$, the supernatant was centrifuged for $5 \mathrm{hr}$ at $77,000 \times \mathrm{g}$. The pellet was suspended in $0.05 \mathrm{M}$ Tris buffer, $\mathrm{pH} 7.5$. After centrifugation for $20 \mathrm{~min}$ at $22,000 \times g$, the supernatant was centrifuged for $2 \mathrm{hr}$ at $140,000 \times \mathrm{g}$. The pellet was suspended in $2 \mathrm{ml}$ of Tris buffer and the suspension was centrifuged for $10 \mathrm{~min}$ at $10,000 \times \mathrm{g}$. The supernatant was 
layered onto a column of $20 \%$ and $35 \%$ sucrose solution (12.5 ml each) and centrifuged for $2 \mathrm{hr}$ at $24,000 \mathrm{rpm}$ in a Hitachi RPS-25A rotor. Two $\mathrm{ml}$ of the zone between $20 \%$ and 35\% sucrose layers was recovered with a tip-bent needle with syringe. The fraction was diluted with Tris buffer and centrifuged for $2 \mathrm{hr}$ at $140,000 \times \mathrm{g}$. The pellet was suspended in $1 \mathrm{ml}$ of Tris buffer and considered to be purified.

The filamentous nucleoprotein was also purified from RGS-infected rice plants following the procedure descrived by Hibino et al. ${ }^{3}$.

Electron microscopy. The purified fraction was diluted appropriately with distilled water, mounted on carbon-coated collodion grids, and stained with $1 \%$ or $2 \%$ uranyl acetate. The grids were examined in a Hitachi $\mathrm{H}-500$ electron microscope.

Antiserum production. Approximately $1 \mathrm{ml}$ of the purified fraction was injected five times into a domestic rabbit at weekly intervals. In the first to third injections, the antigen emulsified with an equal volume of Freund's complete adjuvant was given intramuscularly and hypodermically. The fourth and last injections were given intravenously. Antiserum was recovered one week after the last injection. The serum was tested by the microprecipitin test and its titer against purified RGS-antigen was $1 / 256$, while its titer against a fraction similarly purified from healthy rice plants was $1 / 16$.

Agar gel double diffusion test. Ten $\mathrm{m} 1$ of $0.8 \%$ Difco Bacto agar containing 0.15 $\mathrm{M}$ sodium chloride and $0.1 \%$ sodium azide was placed in a $90-\mathrm{mm}$ diameter plastic petri dish. Six peripheral wells, $2 \mathrm{~mm}$ in diameter, were spaced $2 \mathrm{~mm}$ apart around a central well. The antiserum absorbed with healthy leaf sap was added into the central well. Saps of the infected and healthy rice leaves, and extracts of viruliferous and virus-free planthoppers were clarified by stirring with $20 \%$ of $\mathrm{CCl}_{4}$ and by one cycle of differential centrifugation for $15 \mathrm{~min}$ at $10,000 \times \mathrm{g}$ and for $2 \mathrm{hr}$ at $140,000 \times \mathrm{g}$, and used as antigens.

Infectivity neutralization test. Immunoglobulin ( $\mathrm{IgG}$ ) was purified from the antisera to RGS and to bean common mosaic virus (BCMV) ${ }^{10)}$ by ammonium sulfate precipitation and DEAE-cellulose column chromatography. The infected-rice leaf sap was clarified by differential centrifugation and mixed with the same volume of IgG or 0.15 $\mathrm{M}$ sodium chloride. The mixture was injected into the abdomens of second or thirdinstar nymphs by using fine glass capillaries. These insects were fed on healthy rice seedlings for 12 days and individually allowed a 2-day inoculation access period on test seedlings.

ELISA. The procedures essentially followed the method described by Clark and Adams $^{1)}$. Extraction buffer and assessment of the reaction described by Hibino and Kimura were applied ${ }^{2)}$. Micro-ELISA Immuron Plates (Cooke Laboratory Products, CK 223-24) were used, and the appropriate concentrations of coating $\gamma$-globulin and $\gamma^{-}$ globulin-alkaline phosphatase conjugate for detecting RGS-associated filaments in viruliferous insects were $1.25 \mu \mathrm{g} / \mathrm{ml}$ and $1 / 800$ dilution, respectively. Absorbance at $405 \mathrm{~nm}$ below 0.07 was considered negative.

\section{Results}

\section{Electron microscopy of purified filaments}

The filamentous particles $6-12 \mathrm{~nm}$ in width and indeterminate host components were 


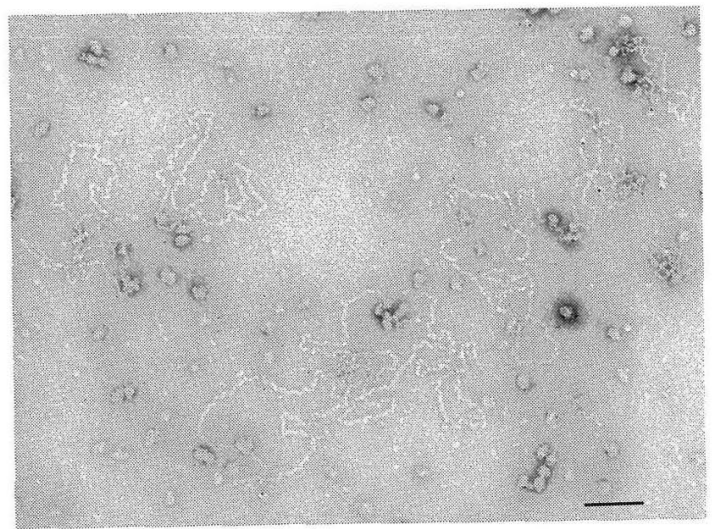

Fig. 1. Electron micrograph of the filaments in a purified fraction stained with uranyl acetate. Scale bar represents $100 \mathrm{~nm}$.

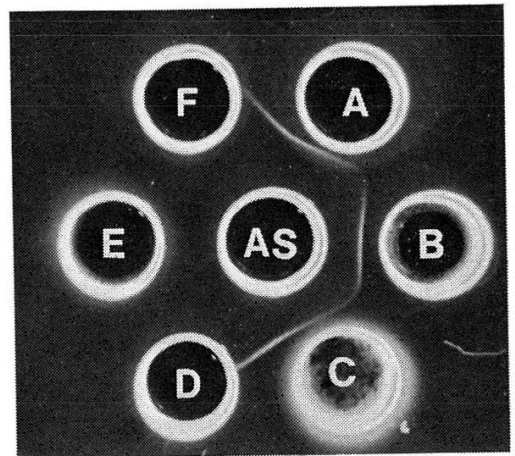

Fig. 2. Reactions between antiserum to the filaments (AS), and the infected rice sap (A), purified filamentous nucleoprotein (B), extract of viruliferous $N$. lugens (C), $0.15 \mathrm{M} \mathrm{NaCl}$ (D), extract of virus-free $N$. lugens (E), and healthy plant sap (F) in agar gel diffusion test.

observed in the preparations of the purified fraction (Fig. 1). The filamentous particles showed a frizzly loop-like structure.

\section{Agar gel double diffusion test}

Single reaction bands were produced between the antiserum and the wells with extracts of the infected leaves and viruliferous planthoppers, and purified filamentous nucleoprotein (Fig. 2). These bands fused each other. The antiserum did not produce reaction bands with the extracts of healthy leaves and virus-free insects.

\section{Infectivity neutralization test}

Mixtures of RGS-infected leaf sap with $0.15 \mathrm{M}$ sodium chloride or IgG to BCMV were infective in the injection test. While, infected leaf sap mixed with IgG to RGSassociated filaments lost its infectivity (Table 1).

\section{Detection of filaments by ELISA}

RGS-associated filaments were detected in extracts of viruliferous-planthopper popu-

Table 1. Effects of immunoglobulin to grassy stunt associated filaments (RGSV) or bean common mosaic virus (BCMV) on infectivity of grassy stuntinfected leaf sapa)

\begin{tabular}{c|c}
\hline \hline Infected leaf sap mixed with & Planthoppers transmitting/injected (No.) \\
\hline 0.15 M NaCl & $6 / 20$ \\
Anti-BCMV (1 mg/ml) & $6 / 16$ \\
do $(0.1 \mathrm{mg} / \mathrm{ml})$ & $21 / 46$ \\
Anti-RGSV (1 mg/ml) & $0 / 18$ \\
do (0.1 mg/ml) & $0 / 22$ \\
\hline
\end{tabular}

a) The infected leaf sap was mixted with immunoglobulin (1:1 in volume) and injected into the abdomen of brown planthopper nymphs. The injected brown planthoppers were tested for infectivity. 


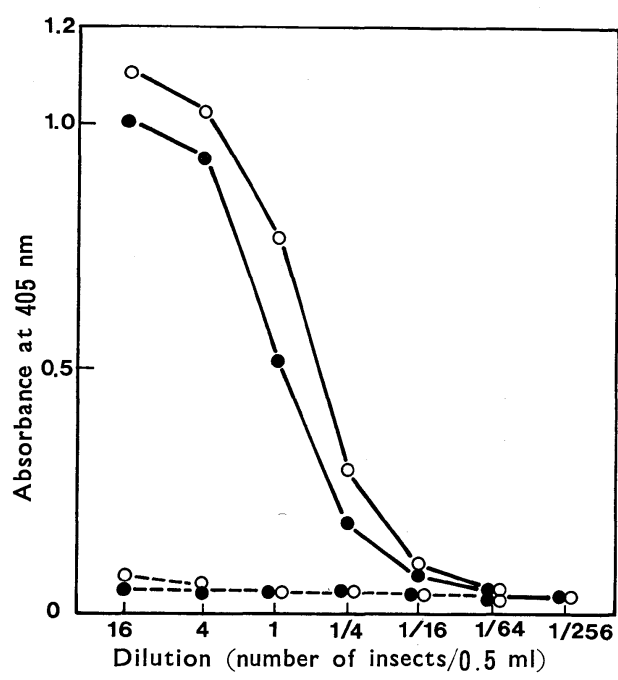

Fig. 3. Reactions of extracts of viruliferous (and virus-free (......) N. lugens in ELISA. Sixty four individuals were homogenized with $2 \mathrm{ml}$ of extraction buffer and the homogenate was diluted sequentially 4 times. Male $=$, female $=\bigcirc$.

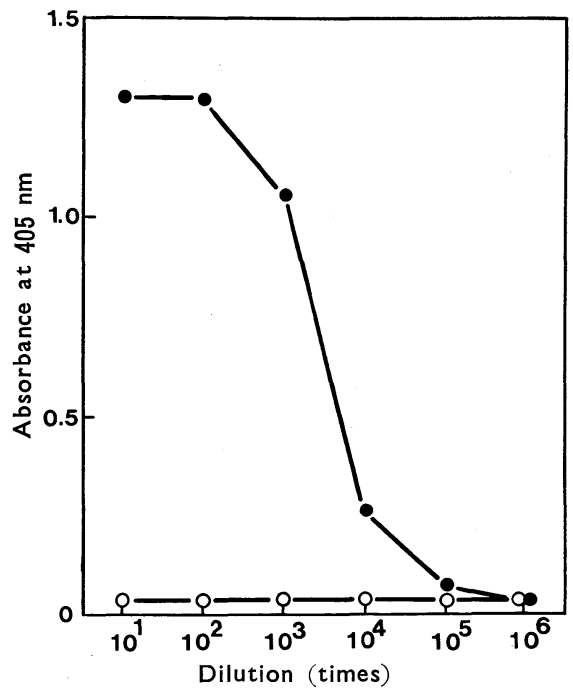

Fig. 4. Reactions of extracts of rice grassy stunt-infected (2) and healthy (O) rice leaves in ELISA.

lations (one planthopper per $0.5 \mathrm{ml}$ ) even when they were diluted 16 times in ELISA (Fig. 3). Absorbance at $405 \mathrm{~nm}$ obtained from viruliferous females was higher than that from viruliferous males. Extracts of virus-free planthoppers gave negative reactions.

The filaments in extracts of RGS-infected rice leaves were detected up to $1 / 100,000$ dilution, while extracts of healthy leaves did not give positive reaction (Fig. 4). Extracts of rice leaves infectes with the other rice viruses and mycoplasma-like organism, such as dwarf, ragged stunt, stripe, yellow dwarf and waika, gave negative reactions (Table 2). The purified filamentous nucleoprotein reacted positively even when the fraction was diluted to $A_{260}=1.0 \times 10^{-5}$.

Table 2. Reactions of extracts of rice leaves infected with rice viruses or mycoplasm-like organism in ELISA

\begin{tabular}{l|c|c|c|c}
\hline \hline \multirow{2}{*}{ Leaf extracts } & \multicolumn{3}{|c}{$\mathrm{A}_{405}$ of leaf extracts in ELISA } \\
\cline { 2 - 5 } & \multicolumn{3}{|c}{ Dilution (times) } \\
\cline { 2 - 5 } & 10 & 100 & 1,000 & 10,000 \\
\hline Grassy stunt & 1.06 & 1.03 & 0.82 & 0.12 \\
Dwarf & 0.05 & 0.05 & 0.04 & 0.04 \\
Ragged stunt & 0.05 & 0.05 & 0.04 & 0.05 \\
Stripe & 0.05 & 0.05 & 0.05 & 0.04 \\
Yellow dwarf & 0.05 & 0.05 & 0.05 & 0.05 \\
Waika & 0.05 & 0.05 & 0.04 & 0.04 \\
Healthy & 0.05 & 0.05 & 0.05 & 0.04 \\
\hline
\end{tabular}




\section{Detection of the filaments from stored planthoppers and rice leaves}

Infective planthoppers were stored at $25 \mathrm{C}, 5 \mathrm{C}$ or $-20 \mathrm{C}$ for 11 or 31 days, and then their extracts were individually tested by ELISA. All infective planthoppers stored gave positive reactions (Table 3). A lower absorbance was observed in the extracts of insects stored at higher temperatures for a longer period of time. Especially the values were much lower in extracts of some males stored at $25 \mathrm{C}$.

Table 3. Effects of storage at 25.5 and $-20 \mathrm{C}$ for 11 or 31 days on detection of rice grassy stunt-associated filaments in the infective brown planthoppers by ELISA

\begin{tabular}{|c|c|c|c|c|}
\hline \multirow{3}{*}{ Temperature } & \multicolumn{4}{|c|}{ Average $\mathrm{A}_{405}$ of extracts in ELISA ${ }^{\text {a) }}$} \\
\hline & \multicolumn{2}{|c|}{11 days' storage } & \multicolumn{2}{|c|}{31 days' storage } \\
\hline & Male & Female & Male & Female \\
\hline $25 \mathrm{C}$ & $\begin{array}{c}0.16 \\
\left.(0.11-0.21)^{b}\right)\end{array}$ & $\begin{array}{c}0.70 \\
(0.18-1.07)\end{array}$ & $\begin{array}{c}0.10 \\
(0.08-0.14)\end{array}$ & $\begin{array}{c}0.45 \\
(0.14-0.79)\end{array}$ \\
\hline $5 \mathrm{C}$ & $\begin{array}{c}0.64 \\
(0.37-0.89)\end{array}$ & $\begin{array}{c}1.18 \\
(1.11-1.25)\end{array}$ & $\begin{array}{c}0.34 \\
(0.19-0.65)\end{array}$ & $\begin{array}{c}0.91 \\
(0.48-1.12)\end{array}$ \\
\hline$-20 \mathrm{C}$ & $\begin{array}{c}1.13 \\
(1.20-1.40)\end{array}$ & $\begin{array}{c}1.39 \\
(1.37-1.40)\end{array}$ & $\begin{array}{c}1.12 \\
(0.91-1.24)\end{array}$ & $\begin{array}{c}1.19 \\
(0.54-1.30)\end{array}$ \\
\hline
\end{tabular}

a) A total of 6-8 brown planthoppers was individually homogenized with $0.5 \mathrm{ml}$ of extraction buffer and the homogenate was tested by ELISA. Extracts of virus-free insects which had been stored under the same conditions gave $A_{405}$ values $<0.05$.

b) Numbers in the parenthesis indicate range.

Table 4. Effects of storage at $-80 \mathrm{C}$ or at room temperature for 4 months on detection of rice grassy stunt-associated filaments in grassy stunt-infected rice by ELISA.

\begin{tabular}{|c|c|c|c|c|c|}
\hline \multirow{3}{*}{ Rice leaves stored at } & \multicolumn{5}{|c|}{$\mathrm{A}_{405}$ of extracts in ELISA } \\
\hline & \multicolumn{5}{|c|}{ Dilution (times) } \\
\hline & 10 & 100 & 1,000 & 10,000 & 100,000 \\
\hline $\begin{array}{l}-80 \mathrm{C} \\
\text { infected } \\
\text { healthy }\end{array}$ & $\begin{array}{l}1.31 \\
0.06\end{array}$ & $\begin{array}{l}1.30 \\
0.05\end{array}$ & $\begin{array}{l}1.25 \\
0.04\end{array}$ & $\begin{array}{l}0.81 \\
0.05\end{array}$ & $\begin{array}{l}0.40 \\
0.05\end{array}$ \\
\hline $\begin{array}{c}\text { Room temperature } \\
\text { infected } \\
\text { healthy }\end{array}$ & $\begin{array}{l}1.18 \\
0.04 \\
\end{array}$ & $\begin{array}{l}1.08 \\
0.04 \\
\end{array}$ & $\begin{array}{l}0.56 \\
0.04\end{array}$ & $\begin{array}{l}0.12 \\
0.04 \\
\end{array}$ & $\begin{array}{l}0.06 \\
0.04 \\
\end{array}$ \\
\hline $\begin{array}{l}\text { Fresh } \\
\begin{array}{l}\text { infected } \\
\text { healthy }\end{array}\end{array}$ & $\begin{array}{l}1.32 \\
0.06\end{array}$ & $\begin{array}{l}1.30 \\
0.05\end{array}$ & $\begin{array}{l}1.24 \\
0.05\end{array}$ & $\begin{array}{l}0.45 \\
0.05\end{array}$ & $\begin{array}{l}0.34 \\
0.05\end{array}$ \\
\hline
\end{tabular}

Extracts of RGS-infected rice leaves stored at $-80 \mathrm{C}$ for 4 months reacted similarly to those of fresh leaves (Table 4). Extracts of infected leaves stored at room temperature for 4 months gave positive reaction up to $1 / 10,000$ dilution.

\section{Detection of the filaments in individual planthoppers}

Infectivity of individual planthoppers was tested and the planthoppers were then 
Table 5. Relations between infectivity of the brown planthoppers and the intensity of reactions of their extracts in ELISA

\begin{tabular}{l|r|r|r|r|r|r}
\hline \hline \multirow{2}{*}{$\mathrm{A}_{405}$ values in ELISA } & \multicolumn{9}{|c}{ Number of insects } \\
\cline { 2 - 7 } & \multicolumn{2}{|c|}{ Infective $^{\mathrm{a})}$} & \multicolumn{2}{|c|}{ Noninfective } & \multicolumn{2}{c}{ Virus-free $^{\mathrm{b})}$} \\
\cline { 2 - 7 } & Male & Female & Male & Female & Male & Female \\
\hline $0.00-0.07$ & 0 & 0 & 3 & 19 & 14 & 14 \\
$0.07-0.2$ & 1 & 1 & 26 & 0 & 0 & 0 \\
$0.2-0.4$ & 0 & 0 & 0 & 0 & 0 & 0 \\
$0.4-0.6$ & 0 & 0 & 1 & 1 & 0 & 0 \\
$0.6-0.8$ & 0 & 1 & 0 & 0 & 0 & 0 \\
$0.8-1.0$ & 9 & 1 & 3 & 2 & 0 & 0 \\
$1.0-$ & 10 & 19 & 1 & 7 & 0 & 0 \\
\hline
\end{tabular}

a) Insects allowed a 7 day acquisition access period were fed on healthy seedlings for 5 days and tested for their infectivity in a 2 day inoculation access period.

b) Insects not allowed to feed on a grassy stunt-infected rice plant.

Table 6. Detection of rice grassy stunt-associated filaments in immigrant brown planthoppers collected at various locations in 1982 by ELISA

\begin{tabular}{l|l|c|c}
\hline \hline Location & Methods of collection & $\begin{array}{c}\text { Total number of } \\
\text { insects tested }^{\text {a) }}\end{array}$ & $\begin{array}{c}\text { No. of batches that } \\
\text { reacted in ELISA }\end{array}$ \\
\hline Chikugo, Fukuoka & Aspirator & 212 & 0 \\
Isahaya, Nagasaki & Light trap & 657 & 1 \\
East China Sea ${ }^{\mathrm{b})}$ & Airborne net trap & 257 & 0 \\
\hline
\end{tabular}

a) Two to five insects were tested in a batch.

b) Collected in weather observatory station at $\mathrm{N} 37^{\circ} 30^{\prime}, \mathrm{E} 127^{\circ}$ on the East China Sea.

separately homogenized with $0.5 \mathrm{ml}$ of extraction buffer for ELISA. Extracts of all infective planthoppers gave positive reactions (Table 5). Extracts of many noninfective planthoppers gave $A_{4: 5}$ values $<0.2$, while some of them gave values $>0.8$. All virusfree insects gave negative reactions. In the planthoppers fed on a infected rice plant, $81 \%$ of the insects gave positive reactions by ELISA and $40 \%$ of them were infective.

\section{Detection of filaments in immigrant planthoppers}

Two to five planthoppers in a group were homogenized with $0.5 \mathrm{ml}$ of extraction buffer and the extracts were tested by ELISA. A total of 1,126 planthoppers was tested and only one sample containing two planthoppers reacted positively (Table 6).

\section{Discussion}

Association of isometric ${ }^{15)}$ and filamentous ${ }^{3)}$ particles with RGS has been reported. In these experiments, the fraction obtained by basically following the purification procedures for the isometric particles ${ }^{15)}$ were found to contain filamentous particles similar to the circular filamentous nucleoprotein reported by Hibino et al. ${ }^{3)}$. Isometric particles 
were not observed in the fractions. The antiserum to the purified fraction specifically reacted to the extracts of RGS-infected leaves and-viruliferous planthoppers. The antiserum also reacted to the purified filamentous nucleoprotein. The antibody neutralized the infectivity in extracts of RGS-infected rice leaves. These results support the findings of Hibino et al. ${ }^{3)}$ indicating that filamentous nucleoprotein may correspond to the grassy stunt disease agent. It is evident that the major antigen in the purified fractions was the filamentous nucleoprotein which was referred to as "rice grassy stunt virus" (RGSV) ${ }^{3)}$.

Although the purified "filament fractions" contained some cellular components, the antiserum obtained could be used for ELISA. Our study indicates that ELISA is a very efficient test for the detection of "RGSV" in the infected plants and viruliferous insects. The infectivity test can be applied for the identification of RGSV-carrying planthoppers, but it is laborious and time-consuming, and requires living planthoppers. ELISA is adequate for a large number of samples, and applicable to dried and stored samples. Latex flocculation test has been reported as a simple and efficient method of serodiagnosis for RGSV ${ }^{12)}$. Although this test is easier to perform and requires less than 1 hour to detect the virus, it is less sensitive than ELISA and not quantitative.

Some planthoppers gave a high ELISA value but did not transmit the causal agent. Similar phenomena have been reported in the other rice virus diseases ${ }^{2,5,11,16)}$.

In the 1982 trial, RGSV-carriers accounted for $0.1 \%$ of the immigrant populations collected. This finding is in agreement with the results of infectivity tests obtained using immigrant brown planthoppers in 1979-19834). These results suggest that RGSV is apparently brought to Japan through brown planthopper migration every year. The immigration occurs in Kyushu every year in June-July when rice is at the seedling or early tillering stages. It is not surprising that only $0.1 \%$ of the immigrants caused RGSV problems in Kyushu, because a great number of immigrants fly over Kyushu each year. Sometimes more than a thousand immigrants were caught by light trap in one night at Kagoshima or Nagasaki. In such cases, many catches can be homogenized in batches and the presence of one RGSV carrier in the batch can be detected in ELISA $^{6}$.

The authers wish to thank Dr. H. Hibino, the International Rice Research Institute, Philippines, for review and criticism of this manuscript.

\section{Literature cited}

1. Clark, M. F. and Adams, A. N. (1977). J. Gen. Virol. 34:475-483.

2. Hibino, H. and Kimura, I. (1982). Phytopathology $72: 656-659$.

3. Hibino, H., Usugi, T., Omura, T., Tsuchizaki, T., Shohara, K. and Iwasaki, M. (1985). Phytopathology 75 (in press).

4. Hirao, J., Inoue, H. and Ôya, S. (1984). Appl. Ent. Zool. 19:257-259.

5. Horita, M., Tsushima, S., Uyeda, I. and Shikata, E. (1983). Memo. Fac. Agr. Hokkaido Univ. $13: 551-558$.

6. Iwasaki, M. (1985). Transmission of Plant and Animal Viruses by Vectors (Hidaka, J. et al. eds.) (in press).

7. Iwasaki, M., Nakano, M. and Shinkai, A. (1980). Ann. Phytopath. Soc. Japan $46: 411$ (abstr.).

8. Iwasaki, M. and Shinkai, A. (1979). Ibid. $45: 741-744$. 
9. Ling, K. C., Tiongco, E. R. and Aguiero, V. M. (1970). Plant Dis. Reptr. 54:565-569.

10. Nakano, M., Negishi, H., Iwasaki, M. and Shinkai, A. (1983). Proc. Assoc. Pl. Prot. Kyushu $29: 6-9$.

11. Omura, T., Hibino, H., Usugi, T., Inoue, H., Morinaka, T., Tsurumachi, S., Ong, C. A., Putta, M., Tsuchizaki, T. and Saito, Y. (1984). Plant Disease 68:374-378.

12. Pellegrini, S. and Bassi, M. (1978). Phytopatho. Z. $92: 247-250$.

13. Rivera, C. T., Ou, S. H. and Iida, T. T. (1966). Plant Dis. Reptr. $50: 453-456$.

14. Senboku, T. and Shikata, E. (1980). Ann. Phytopath. Soc. Japan $46: 487-493$.

15. Shikata, E., Senboku, T. and Ishimizu, T. (1980). Proc. Japan Acad. 56(B) : 89-94.

16. Tsuzuki, H., Koide, H., Nishioka, M., Miyajima, S., Imamura, S. and Nakanishi, I. (1973). Res. Bull. Aichi Agric. Res. Centr. A $5: 57-62$.

\section{和 文 摘 要}

岩崎真人・中野正明・新海 昭: 酵素結合抗体法 (ELISA) によるトビイロウンカおよびイネからのイネグ ラッシースタントゥイルスの検出

イネグラッシースタントウイルス感染水稲から径 6-12 nm のひす状粒子を純化し，抗血清を作製した。寒 天ゲル内二重拡散法によって抗血清の性状を調べたところ, 感染水稲汁液, 保毒トビイロウンカ磨砕液㧠よび Hibino et al. (1985) の方法で純化した filamentous nucleoprotein と特異的に反応し, 沈降線は融合した。 本抗血清から精製した $\gamma$-グロブリンは, 感染葉汁液の感染性を中和した。ひす状粒子は, 酵素結合抗体法 （ELISA）によって 1 個体 $/ 8 \mathrm{ml}$ まで希釈した獲得吸汁虫集団の磨砕液拈よび $10^{-5}$ に希釈した感染葉汁液加ら 検出され，無毒虫磨研液抢よび健全葉汁液から検出されなかった。純化した filamentous nucleoprotein は， $\mathrm{A}_{260}=1.0 \times 10^{-5}$ に希釈した場合も ELISA で反応が認められた。25Cで 1 か月保存した媒介虫扰よび室温で 4 か月保存した感染葉も陽性であったが，凍結保存および新鮮な材料と比較すると反応は低下した。獲得吸汁 虫を個体別に媒介の有無と ELISA での反応を調べたところ，ともに陽性であった個体は40\%，ELISA が陽 性で媒介の認められなかった個体は41\%，ともに陰性であった個体は19\%であった。1982年に1,126頭の海外 飛来トビイロウンカを供して ELISA によって本ウイルスの保有の有無を検定した。陽性の反応が認められた 個体は1頭（約 $0.1 \%$ )であった。 